\title{
Effectiveness of the Implementation Good Corporate Governance and Financial Performance on the Quality of Sustainability Reporting Disclosure
}

\author{
Putri Dwi Wahyuni $^{1^{*}}$, Angela Dirman ${ }^{2}$, Oktavia $^{3}$, Septian Bayu Kristanto ${ }^{4}$ \\ ${ }^{1,2}$ Faculty of Economics and Business, Universitas Mercu Buana, Jakarta, Indonesia \\ ${ }^{3,4}$ Universitas Kristen Krida Wacana, Jakarta Indonesia
}

DOI: $10.36348 /$ SJEF.2019.v03i12.001 | Received: 25.11.2019| Accepted: 02.12.2019| Published: 06.12.2019

*Corresponding author: Putri Dwi Wahyuni

\section{Abstract}

This study aims to examine the effectiveness of the implementation Good Corporate Governance (GCG) and financial performance on the quality of sustainability reporting disclosure. The dependent variable used in this study is the quality of sustainability reporting disclosure which is proxied by the G4 Sustainability Reporting Index (SRI), while the independent variable is good corporate governance (the proportion of independent commissioners and audit committee meetings) and the financial ratio dimensions (net profit margin, debt to equity ratio and price earnings ratio). The population in this study are companies listed on the Indonesia Stock Exchange in 2016-2017. The sample in this study was selected using the purposive sampling method and as many as 92 observational samples were obtained. The analysis technique used in this study is multiple linear regression analysis. The results of this study indicate that only the debt to equity ratio variable has a significant effect on the quality of sustainability reporting disclosure while the variable proportion of independent commissioners, audit committee meetings, net profit margins and price earning ratios have an effect but not significantly on sustainability reporting disclosure

Keywords: Sustainability Reporting, GCG, Financial Performance.

Copyright @ 2019: This is an open-access article distributed under the terms of the Creative Commons Attribution license which permits unrestricted use, distribution, and reproduction in any medium for non-commercial use (NonCommercial, or CC-BY-NC) provided the original author and source are credited.

\section{PRELIMINARY}

At present, companies no longer think about profit-oriented in creating goods and services but instead focus on long-term goals by taking into account the interests of the stakeholders. Environmental issues are not new issues in social life. Environment both in the sense of nature as well as social and economic conditions consciously or not have something close enough attachment, where humans as social communities will influence each other which will have an impact on environmental changes both natural, social, and economic conditions that are around it. The goal of obtaining large profits (the concept of a single bottom line) is no longer the main thing in achieving business success but is turned into a triple bottom line concept (profit, people, plant) that is profit related to economic aspects, people related to social aspects, related planet with environmental aspects.

Since the development of issues regarding corporate social responsibility (CSR) and sustainability the company has become the main focus of its role in the environment. Due to a series of incidents of environmental and humanitarian damage in Indonesia, such as cases of conflict and environmental damage by a cement factory in Rembang and the Sidoarjo Mud Flood in Sidoarjo by PT Lapindo Brantas. This is due to the company's lack of concern for the environment and low social responsibility. Information on the impact of the company's economic, social and environmental activities can be disclosed through the sustainability report as a voluntary report that is presented separately from the annual report.

Sustainability Report is a form of report that is carried out by a company in order to disclose or communicate to all stakeholders regarding environmental, social and good governance performance in an accountable manner. Sustainability reporting disclosure in Indonesia is still limited to voluntary. Even though it is still voluntary, almost $9 \%$ of companies listed on the Jakarta Stock Exchange (IDX) have published sustainability reports. The issuance of sustainability reports that exist in Indonesia at this time, almost mostly based on disclosure standards that exist in the Global Reporting Index 
(GRI). As of the end of 2016, 49 IDX listing companies have issued sustainability reports. 12 Financial Services Institutions (LJK) have issued sustainability reports.
The 12 LJK consist of 8 BUKU 3 banks and 4 BUKU 4 banks [1].

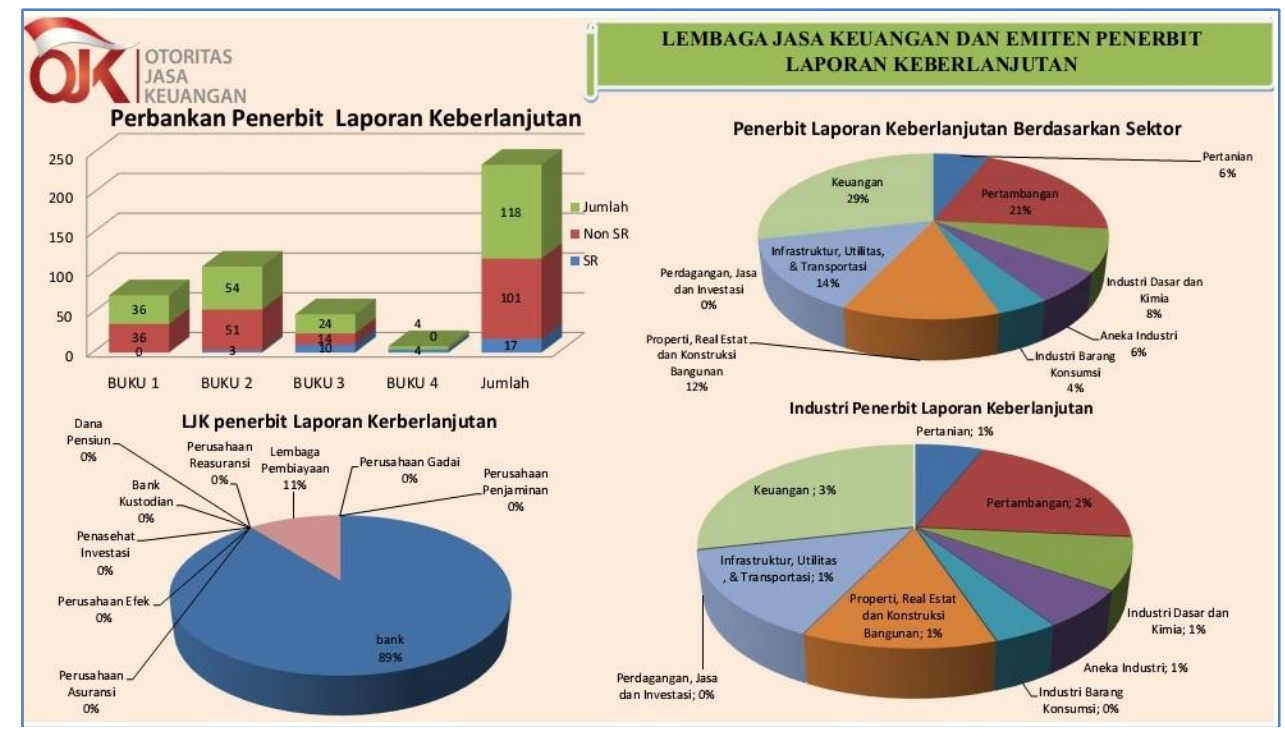

Companies that have gone public on the Indonesia Stock Exchange must implement good corporate governance. The implementation of GCG is one of the pillars of a market economy. The implementation of GCG will encourage the creation of a healthy business climate for the business world. The practice and disclosure of sustainability report is the implementation of the concept and mechanism of Good Corporate Governance which has the principle that stakeholders need attention, both in terms of existing rules and establish active cooperation for long-term survival between stakeholders and the company. The supporting infrastructure for the practice and disclosure of sustainability reports is the mechanism and structure of governance in the company [2]. Financial statements are quantitative information that is very attractive to investors. Profitability is a proxy for future prospects and corporate liquidity is a proxy for going concern of the company in the future. Expectations of the company's prospects and risks in the future will have an impact on stock price volatility [3].

Corporate awareness in reporting Sustainability Reports is seen because it can help organizations to set goals, measure performance, and manage change in order to make their operations more sustainable [4]. Companies that have good financial performance capabilities will be synonymous with efforts to make broader disclosures so that they have high confidence to inform their stakeholders because the company is able to show them that the company can meet their expectations, especially investors and creditors.

According to [5] states that the variables of the audit committee, governance committee and leverage have a positive effect on the disclosure of sustainability reports while the variables of the independent board of commissioners, managerial ownership and profitability do not affect the disclosure of the sustainability report[6]. stated that there was a significant positive correlation between sustainability disclosure and the attributes of the composition of the company board that supported the mechanism of better corporate governance. These attributes include the proportion of independent councils, the number of councils and directors of women in the composition of the council[7, 8]. Showed the results of research that the number of audit committee meetings and governance committees affected the disclosure of sustainability reports.

The purpose of this study is to examine the effect of the proportion of independent commissioners, audit committee meetings, net profit margins, debt to equity ratio and price earning ratio on the quality of sustainability reporting disclosure. This research update is for measuring sustainability reporting using the Global Reporting Initiative (GRI - G4). In addition, financial performance is measured by several dimensions, namely the dimensions of profitability, leverage and market.

\section{RESEARCH METHODS}

This type of research is causal research that explains the effect of an independent variable on the dependent variable. The independent variables in this study include good corporate governance and financial performance while the dependent variable is the quality of sustainability reporting disclosure.

The population of this study is companies listed on the Indonesia Stock Exchange for the period of 2016 - 2017. The sample in this study amounted to 46 issuers 
with 2 years of research so that the number of research data amounted to 92 observations.

The sampling method used was purposive sampling in order to obtain a representative sample in accordance with specified criteria. The criteria used are as follows:

- Companies listing on the Indonesia Stock Exchange before 2016

- Companies that publish annual reports and sustainability reporting in 2016 and 2017

- Companies that did not do mergers and acquisitions in 2016 and 2017

The data analysis method in this study uses SmartPLS version 3.0 software which is run on computer media. PLS (Partial Least Square) is a variance-based structural equation analysis (SEM) that can simultaneously test measurement models as well as structural model testing. The measurement model is used to test the validity and reliability, while the structural model is used to test causality (hypothesis testing with predictive models). PLS is characterized as a technique most suitable where the research purpose is prediction or exploratory modeling. In general, covariance-based SEM is preferred when the research purpose is confirmatory modeling. PLS is less than satisfactory as an explanatory technique because it is low in power to filter out variables of minor causal importance Tobias 1997 [9] in Garson [1].

\section{Data analysis methods in this study are divided into two namely Descriptive Statistics Analysis}

Empirical analysis in the description of the information obtained to provide an overview / describe about an event (who / what, when, where, how, how much) collected in the study.

\section{Inferential Statistical Analysis}

In accordance with the hypotheses that have been formulated, in this study inferential statistical data analysis is measured using SmartPLS software (Partial Least Square) starting from the measurement model (outer model), structure model (inner model) and hypothesis testing.

\begin{tabular}{|c|c|c|c|}
\hline No & Variabel & Definition & Measurement \\
\hline 1 & $\begin{array}{l}\text { Sustainability } \\
\text { Reporting } \\
\text { Disclosure }\end{array}$ & $\begin{array}{l}\text { According to the Global Reporting Initiative [3] } \\
\text { sustainability report is the practice of measurement, } \\
\text { disclosure, and accountability efforts of } \\
\text { organizational performance in achieving sustainable } \\
\text { development goals to stakeholders both internal and } \\
\text { external for organizational performance in achieving } \\
\text { sustainable development goals }\end{array}$ & $\begin{array}{l}\text { If the company discloses an item then it is } \\
\text { given a value of } 1 \text { and if it does not disclose it } \\
\text { is given a value of } 0 \text {. Furthermore, each item is } \\
\text { added together, then divided by the total } \\
\text { number of disclosures based on the Global } \\
\text { Reporting Initiative (GRI - G4) of } 149 \text { items. } \\
\text { SRD = (number of items disclosed / 149) x } \\
100 \%\end{array}$ \\
\hline 2 & $\begin{array}{l}\text { Independent } \\
\text { Board of } \\
\text { Commissioners }\end{array}$ & $\begin{array}{l}\text { Independent Commissioners are members of the } \\
\text { board of commissioners who are not affiliated with } \\
\text { the Board of Directors, other members of the board } \\
\text { of commissioners and controlling shareholders, and } \\
\text { are free from business relationships or other } \\
\text { relationships that can affect their ability to act } \\
\text { independently or act solely in the interests of the } \\
\text { company. }\end{array}$ & $\frac{\sum \text { independent commissioner member }}{\sum \text { member of the board of commissioners }}$ \\
\hline 3 & $\begin{array}{l}\text { audit committee } \\
\text { meeting }\end{array}$ & $\begin{array}{l}\text { In this study, the audit committee is measured } \\
\text { through the number of meetings held by the audit } \\
\text { committee in one year [4] }\end{array}$ & $\begin{array}{l}\sum_{\text {in one year }}\end{array}$ \\
\hline 4 & $\begin{array}{l}\text { Net Profit } \\
\text { Margin }\end{array}$ & $\begin{array}{l}\text { profitability ratio to assess the percentage of net } \\
\text { income earned after tax deducting from the revenue } \\
\text { earned from sales }\end{array}$ & $N P M=\frac{\text { Earning After Tax }}{\text { Sales }}$ \\
\hline 5 & $\begin{array}{l}\text { Debt to Equity } \\
\text { Ratio }\end{array}$ & $\begin{array}{l}\text { Debt to equity ratio is a measure of the ratio between } \\
\text { total company debt compared with company equity. } \\
\text { Debt to equity ratio shows how much the level of } \\
\text { corporate debt to capital. }\end{array}$ & $D E R=\frac{\text { Total Liabilities }}{\text { Total Equity }}$ \\
\hline 6 & $\begin{array}{l}\text { Price Earning } \\
\text { Ratio }\end{array}$ & Ratio of market price per share to net profit per share & $P E R=\frac{\text { Market Value Price per Share }}{\text { Earnings per Share }}$ \\
\hline
\end{tabular}




\section{RESULTS AND DISCUSSION \\ Results \\ Statistik Deskriptif}

\begin{tabular}{|l|c|r|r|r|r|}
\hline \multicolumn{7}{|c|}{ Descriptive Statistics } \\
\hline & \multicolumn{1}{|c|}{ N } & \multicolumn{1}{c|}{ Min } & \multicolumn{1}{c|}{ Max } & \multicolumn{1}{c|}{ Mean } & Std. Deviation \\
\hline Comm_Ind & 92 & 20,00 & 80,00 & 42,1761 & 11,50586 \\
\hline Freq_Aud & 92 & 59,72 & 100,00 & 92,9741 & 9,07738 \\
\hline NPM & 92 & $-176,39$ & 1397,77 & 29,9632 & 155,38723 \\
\hline DER & 92 & $-2,11$ & 14,75 & 2,9082 & 3,10907 \\
\hline PER & 92 & $-230,18$ & 421,47 & 21,5070 & 59,69734 \\
\hline SRD & 92 & 18,79 & 71,14 & 38,9918 & 11,04683 \\
\hline
\end{tabular}

Table 5.1 above is a descriptive statistic of a total of 92 data samples conducted in 2 years of research, with 46 listed companies annually.

1. Proportion of Independent Commissioners. According to the Limited Liability Company Law No. 40 of 2007, Article 108 paragraph (5) explains that for a company in the form of a Limited Liability company, it must have at least 2 (two) members of the Board of Commissioners. The Board of Commissioners consists of independent commissioners and non-independent commissioners. With the existence of an independent commissioner in a company will have a supervisory role in implementing GCG, so the company will be better because the independent commissioner does not have a special relationship with several parties. The above table shows that the mean is 42.17 , which means that the proportion of independent directors has fulfilled the OJK requirements of at least $30 \%$. The maximum value of $80 \%$ is owned by BJBR in 2016 to 2017 . The minimum value of $20 \%$ is owned by TINS in 2016 .

2. Audit Committee Meeting. The American Institute of Certified Public Accountants (AICPA) defines an audit committee as a committee formed by the board of directors with the aim of overseeing the process of accounting and financial reporting and auditing of financial statements. The number of meetings will reflect the effectiveness in communication and coordination between members of the audit committee to realize good corporate governance. The table above shows that the mean of $92.97 \%$, which means the frequency of audit committee meetings has been effective in carrying out supervision and internal control. The maximum value of $100 \%$ is owned by AALI, ABMM, INTP, NISP and others. The minimum value of $59.72 \%$ is owned by WIKA in 2016.

3. Net Profit Margin (NPM) is a ratio used to measure the percentage of net profit on net sales. The table above shows that the mean of $29.96 \%$ which means that net sales to generate profits of $29.96 \%$ is still low. The maximum value of $1397.77 \%$ is owned by BUMI in 2017. The minimum value of $-176.39 \%$ is owned by BNBR in 2016.

4. Debt to Equity Ratio (DER) is a Leverage ratio that shows the long-term ability of a company to pay off its debts if the company is liquidated or dissolved [9]. The table above shows that the mean of 2.91 times, which means the company's debt is greater than the assets owned so that the company's burden on external parties is also large. If the company cannot manage its debt properly and optimally, it will adversely affect the condition of the company's financial health. The maximum value of 14.75 times is owned by BBKP in 2017. The minimum value of -2.11 times is owned by BUMI in 2016 .

5. Price Earnings Ratio (PER) is the ratio of market price per share to net income per share. The table above shows that the mean of $21.51 \%$, which means the market is only willing to pay low on the income or profit of a company that indicates that the market does not have enough confidence in the future of the company's shares in question. The maximum value of 421.47 times is owned by ANTM in 2016. The minimum value of -230.18 times is owned by INCO in 2016.

6. Sustainability Reporting Disclosure (SRD). The Global Reporting Initiative (GRI) defines that Sustainability Report is a measurement, disclosure and accountability effort of an organization's performance in achieving sustainable development goals, reported to both internal and external stakeholders [3]. The table above shows that the mean of $38.99 \%$, which means the disclosure of sustainability reporting is still low so it is difficult to see the company's concern from the public and social side. The maximum value of $71.14 \%$ is owned by AALI in 2016. The minimum value of $18.79 \%$ is owned by BUMI in 2017. 


\section{Evaluation of Measurement Models}

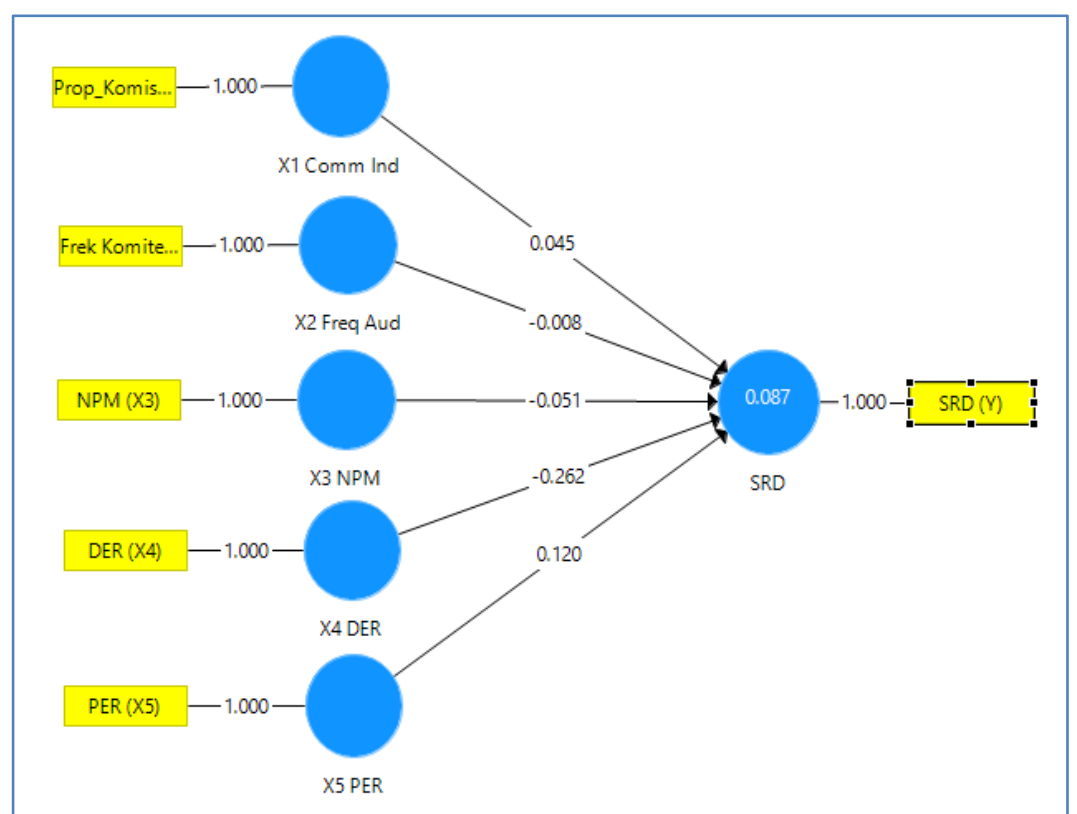

The loading factor illustrates how big the indicators are related to each construct. The path diagram above shows that all indicators have a 1,000 loading factor, which means that all indicators are valid because the loading factor meets the criteria, ie the loading factor of the contract must be above 0.70 . These results indicate a good relationship between the indicators with each construct.

The second check of convergent validity is to look at the value of Cronbach's alpha and composite reliability. The results are as follows:

\begin{tabular}{|l|r|r|r|}
\hline & \multicolumn{3}{c}{ Construct Reliability and Validity } \\
Cronbach's & \multicolumn{2}{l|}{$\begin{array}{l}\text { Composite } \\
\text { Alpha }\end{array}$} & $\begin{array}{l}\text { Average Variance } \\
\text { Extracted (AVE) }\end{array}$ \\
\hline Comm_Ind & 1.000 & 1.000 & 1.000 \\
\hline Freq_Aud & 1.000 & 1.000 & 1.000 \\
\hline NPM & 1.000 & 1.000 & 1.000 \\
\hline DER & 1.000 & 1.000 & 1.000 \\
\hline PER & 1.000 & 1.000 & 1.000 \\
\hline SRD & 1.000 & 1.000 & 1.000 \\
\hline
\end{tabular}

Cronbachs alpha values and composite reliability above 0.7 indicate high reliability of measuring instruments, which means that the gauges of each construct are highly correlated. The third check of convergent validity is to look at the value of AVE. AVE values above 0.5 are highly recommended. From table 5.2 all contracts are 1 or above 0.5 .

\section{Evaluation of Structural Models}

\begin{tabular}{|l|r|r|}
\hline \multicolumn{3}{|c|}{ R Square } \\
\hline & R Square & R Square Adjusted \\
\hline SRD & 0.087 & 0.034 \\
\hline
\end{tabular}

R Square (R2) value of 0.087 means that the variability of the Sustainability Reporting Disclosure construct can be explained by the construct of the Independent Commissioner Proportion, Frequency of
Audit Committee Meetings, Net Profit Margin, Debt to Equity Ratio, and Price Earnings Ratio of $8.7 \%$. While $91.3 \%$ is explained by other variables not found in this study. 


\section{Hypothesis Test Results}

\begin{tabular}{||l|r|r|r|r|r|}
\hline \multicolumn{7}{|c|}{ Value Path Coefficient } \\
\hline & $\begin{array}{c}\text { Original } \\
\text { Sample (O) }\end{array}$ & $\begin{array}{c}\text { Sample } \\
\text { Mean (M) }\end{array}$ & $\begin{array}{l}\text { Standard } \\
\text { Deviation } \\
\text { (STDEV) }\end{array}$ & $\begin{array}{l}\text { T Statistics } \\
(\text { OO/STDEV|) }\end{array}$ & $\begin{array}{l}\text { P } \\
\text { Values }\end{array}$ \\
\hline Comm_Ind -> SRD & 0.045 & 0.029 & 0.149 & 0.303 & $\mathbf{0 . 7 6 2}$ \\
\hline Freq_Aud - > SRD & -0.008 & -0.014 & 0.110 & 0.071 & $\mathbf{0 . 9 4 3}$ \\
\hline NPM -> SRD & -0.051 & -0.034 & 0.144 & 0.356 & $\mathbf{0 . 7 2 2}$ \\
\hline DER -> SRD & -0.262 & -0.229 & 0.122 & 2.150 & $\mathbf{0 . 0 3 2}$ \\
\hline PER - > SRD & 0.120 & 0.127 & 0.073 & 1.659 & $\mathbf{0 . 0 9 8}$ \\
\hline
\end{tabular}

Based on the above table, the results can be used to answer the hypotheses in this study. Hypothesis testing in this study was conducted by looking at the TStatistic value and the P-Value value, it can be seen that the test of the relationship between constructs shows that all constructs are positively related significantly can affect the sustainability reporting disclosure with a value of $\mathrm{T}>1.96$ and $\mathrm{P}$ value $<0.05$. So it can be concluded that only the Debt to Equity Ratio variable towards Sustainability Reporting Disclosure is accepted by the hypothesis.

\section{DISCUSSION}

Proportion of Independent Commissioners on the Quality of Sustainability Reporting Disclosure

The results of testing the first hypothesis indicate that the hypothesis was rejected so it can be said that the proportion of independent directors has an effect but is not significant to the quality of sustainability reporting disclosure. With the existence of an independent commissioner in a company will have a supervisory role in implementing GCG, so the company will be better because the independent commissioner does not have a special relationship with several parties. With a good independent commissioner, there is a disclosure of the company's sustainability report or Sustainability report so that the information contained therein can be used by stakeholders not only financial information but also environmental and social information. However, this contradicts the results because the independent commissioner has not optimally carried out his duties in terms of oversight of management performance, besides that in decisionmakers seen not only a large proportion of independent commissioners but the ability (skill), knowledge, background and competence possessed. This result contradicts the study of [2] showing the proportion of independent commissioners influences the disclosure of sustainability report. But in line with the research of [10] and [5] and [11] who found that the proportion of independent directors did not significantly influence the quality of sustainability report disclosures. This happens because the board of commissioners only works half the time, which means that independent board members are not only the independent board of directors for one company, but more than one company. This makes it difficult for independent board members to understand the complexity of the company's business operations so it is less influential in influencing the decision making process.

\section{Audit Committee Meetings on the Quality of Sustainability Reporting Disclosure}

The results of the second hypothesis testing indicate that the hypothesis was rejected so it can be said that the audit committee meeting had an effect but not significantly to the quality of sustainability reporting disclosure. The existence of an audit committee is believed to be able to create conditions that allow the management concerned to publish sustainability reports that are needed by stakeholders to gain legitimacy from the public. The more frequent audit committee meetings are held, it can improve coordination and improve the implementation of supervision and provide advice on information that must be disclosed in the sustainability report to be better and more effective so that it can affect the disclosure of sustainability reports. Based on stakeholder theory, the company wants to meet the expectations of the stakeholders by making a Sustainability Report that explains the company's activities in the social field and surrounding communities. Therefore, an audit committee was formed to assist management in publishing sustainability reports that are needed by stakeholders to gain legitimacy from the community. However, this is not proven due to lack of supervision, internal control and GCG implementation in the company. The results of the study contradict the research conducted by [12, $13,8]$ show the results of research that the number of audit committee meetings and governance committees influences the disclosure of sustainability reports. However, in line with Pernamasari research [11] which states that audit committee meetings conducted are less effective so it does not affect the disclosures made.

\section{Net Profit Margin on the Quality of Sustainability Reporting Disclosure}

The results of the third hypothesis testing indicate that the hypothesis was rejected so it can be said that the net profit margin has an effect but is not significant to the quality of sustainability reporting disclosure. Based on the theory of legitimacy, the relationship between proxied profitability and net profit margins with sustainability reporting is carried out to obtain positive value and legitimacy from the community that impacts on the profits of the company 
in the coming period. However, these results are not in line because the NPM in this study tends to be low at $29.96 \%$ so that the company's performance is not good which results in the lack of quality sustainability reporting disclosure. This research is in line with [8] which states that companies with high profitability can be sourced from company activities that can adversely affect the environment and society so that companies tend not to do social and environmental disclosure. This result turns out to be in conflict with [14] research showing that Net Profit Margin has a significant effect on the disclosure of sustainability reports in Sustainability Report Awards (ISRA) companies.

\section{Debt to Equity Ratio on the Quality of Sustainability Reporting Disclosure}

The fourth hypothesis testing results indicate that the hypothesis was rejected so it can be said that the debt to equity ratio has a significant effect on the quality of sustainability reporting disclosure. Leverage is a tool to measure how much a company depends on creditors in financing company assets. The effect of debt to equity ratio on sustainability reporting disclosure is because companies with high leverage try to get legitimacy from stakeholders (including creditors and investors) through the sustainability report. The results of this study are in line with [15] found empirical evidence that Debt to Equity Ratio (DER) as a proxy / measure of leverage variables influences the disclosure of sustainability reports that sustainability information can help lenders to determine risk factors associated with company business practices.

\section{Price Earning Ratio on the Quality of Sustainability Reporting Disclosure}

The fifth hypothesis testing results show that the hypothesis was rejected so it can be said that the price earning ratio is influential but not significant to the quality of sustainability reporting disclosure. The $\mathrm{PE}$ ratio measures how much investors are willing to pay per rupiah of current company income. A higher PE ratio shows that the company has future growth prospects[16]. The results of this study are in line with [17] which states that there are no differences in participants in the Indonesia Sustainability Reporting Award.

\section{CONCLUSION}

Based on the results of the hypothesis test, only the debt to equity ratio variable affects the quality of sustainability reporting disclosure. Leverage is a tool to measure how much a company depends on creditors in financing company assets. The effect of debt to equity ratio on sustainability reporting disclosure is because companies with high leverage try to get legitimacy from stakeholders (including creditors and investors) through the sustainability report. While other variables such as independent commissioners, audit committee meetings, net profit margins and price earnings ratio do not affect the quality of sustainability reporting disclosure.

\section{REFERENCES}

1. Garson, G. D. (2016). Partial Least Squares: Regression \& Structural Equation Models. In G. David Garson and Statistical Associates Publishing.

2. Aliniar, D., \& Wahyuni, S. (2017). Pengaruh Mekanisme Good Corporate Governance (Gcg) Dan Ukuran Perusahaan Terhadap Kualitas Pengungkapan Sustainability Report Pada Perusahaan Terdaftar Di Bei. Jurnal Universitas Muhammadiyah Purwekerto, 15(1), 26-41.

3. Utami, W. (2015). Financial Performance and the Quality of Sustainability Disclosure Based on Global Reporting Initiative: Value Relevances Study in Indonesia Stock Exchange. Mediterranean Journal of Social Sciences, 6(5), 243-248.

4. Damanik, L. (2017). Pengaruh Kinerja Keuangan dan Karakteristik Perusahaan Terhadap Kuantitas dan Kualitas Pengungkapan Sustainability Report di Indonesia Periode 2013-2015. Profita, 10(3), 228-246.

5. Aniktia, R., \& Khafid, M. (2015). Pengaruh Mekaniseme Good Corporate Governance Dan Kinerja Keuangan Terhadap Pengungkapan Sustainability Report. Accounting Analysis Journal, 4(3), 1-10.

6. Ong, T., \& Djajadikerta, H. G. (2018). Corporate governance and sustainability reporting in the Australian resources industry: an empirical analysis. Social Responsibility Journal.

7. Sunaryo, K., Fabian, A., \& Dewi, S. (2018). The Effect of Good Corporate Governance and Financial Performance on Sustainability Report Disclosures and its Implications on Corporate Values (Case Study of the IDX Listed Company in 2011-2016). The International Conference on Accounting and Management Science, 196-206.

8. Safitri, M., \& Saifudin. (2019). Implikasi Karakteristik Perusahaan dan Good Corporate Governance Terhadap Pengungkapan Sustainability Report. Jurnal Bingkai Ekonomi, 4(1), 13-25.

9. Tantyo, V., \& Tarigan, J. (2014). Analisa Perbedaan Kinerja Keuangan (Leverage Ratio) Pada Perusahaan Partisipan Indonesia Sustainability Reporting Award (Isra ) 2009-2011. Business Accounting Review, 2(1), 131-140.

10. Aziz, A. (2014). Analisis Pengaruh Good Corporate Governance (GCG) Terhadap Kualitas Sustainability Report. Jurnal Audit Dan Akuntansi Fakultas Ekonomi Universitas Tanjungpura, 3(2), 65-84.

11. Pernamasari, R. (2018). Implementation of Good Corporate Governance and Voluntary Disclosure Compliance: 100 Compass Index Companies Listed Indonesian Stock Exchange (IDX) 2015 - 
2016. International Journal of Academic Research in Accounting, Finance and Management Sciences, 8(2), 235-249.

12. Chariri, A., \& Januarti, I. (2017). Audit committee characteristics and integrated reporting: Empirical study of companies listed on the Johannesburg stock exchange. European Research Studies Journal, 20(4), 305-318.

13. Leksono, A. (2018). Pengaruh Good Corporate Governance, Dan Karakteristik Perusahaan Terhadap Nilai Perusahaan. Jurnal Akuntansi Bisnis, 16(1), 1-18.

14. Arthini, W.N., \& Mimba, P.S.N. (2016). Analisis Perbedaan Kinerja Keuangan Antara Pemenang Dan Bukan Pemenang Indonesia Sustainability
Reporting Awards. E-Jurnal Akuntansi, 14(1), 575-603.

15. Nasir, A., Ilham, E., \& Utara, V. (2014). Pengaruh Karakteristik Perusahaan Dan Corporate Governance Terhadap Pengungkapan Sustainability Report Pada Perusahaan Lq45 Yang Terdaftar. Jurnal Ekonomi Universitas RiauUniversitas Riau, 22(01), 1-18

16. Ross, Westerfield., \& Jaffe. (2003). Corporate Finance. In Corporate Finance, 6.

17. Widyastuti., \& Tarigan, J. (2014). Analisa Perbedaan Kinerja Keuangan (Market Ratio) Pada Perusahaan Partisipan Indonesia Sustainability Report Award (ISRA) 2009-2011. Business Accounting Review, 2(1), 91-99. 